\title{
Integrated regional development and river basin management
}

\author{
M. Bulla \& A. Zseni \\ Department of Environmental Engineering, \\ Széchenyi István University, Hungary
}

\begin{abstract}
The paper presents a multidisciplinary expert system which can be applied in the field of ex-ante assessment both of regional development programmes and river basin management planning. The research introduces the 'complex knowledge space' model which is a further improvement of the environmental management model which was presented during the Conference on Environmental Engineering Education and Training organised by WIT 1996.

Keywords: regional development, river basin management, complex knowledge space model of environmental assessment, water policy integration into sector policies, relevance analysis of rules and other development programmes.
\end{abstract}

\section{Introduction}

River basin management planning essentially refers to the development of the complex utilization of environmental resources. Its information system, databases and indicators can be utilized in regional planning as well as the planning and ex ante evaluation of regional development programs. The common methodology is the Strategic Environmental Assessment (SEA). In addition to presenting the application of SEA, our paper reviews the environmental assessment model and the relevant Hungarian information to be loaded into the complex knowledge space of this environmental assessment model.

The complex knowledge space model is a further improvement of the environmental management model which was presented during the Conference on Environmental Engineering Education and Training organized by the Wessex Institute of Technology in 1996. 
We believe that the environmental assessment expert system, which is a strategic environmental assessment tool, is suitable, and offers mutual support, for both regional development and river basin management planning purposes.

\section{Water management policies: EU Water Frame Directive}

The implementation tool of the EU Water Framework Directive is the river basin management planning. River basin management planning is not merely a water quality improvement program, but one of the largest existing environmental and social programs. It is aimed at achieving all the environmental and economic activities within the borders of natural river basin support a sustainable environmental status and resource management. This is indicated by the goodeven ecologically good - water quality. It is therefore clear that river basin management planning to be performed due to the common determination of the EU shall be connected with regional developments. Development programs, however, call for indicators, because it is impossible to control the achievement of goals without relevant indicators.

\subsection{The content of river basin management plans}

- General description of the river basin, partial water catchment

- Overview of significant loads and impacts of human activities on the condition of surface and underground waters.

- Identification and mapping of areas specified for potable water withdrawal and protected areas.

- Mapping of monitoring networks established for the observation of water condition.

- Mapping in geographical information system.

- List of environmental goals.

- Detailed description of information related to the unfeasibility of original goals.

- Summary of economic analysis made about water utilization.

- Summary of action programs.

- Information to be provided about pollutants and indicators that have thresholds associated with.

- List of programs and plans (availability of integration).

- Summary of actions taken to inform the public and consultations.

- Name and data of competent authority.

- Any documents prescribed by other laws to be included into river basin management plans.

Based on the above, the human impacts and water management issues affecting the given watershed shall be assessed and an action program shall be developed to attain ecological targets (such as good condition or good potential). The river basin management plans including the action program shall be published and submitted for a wide-scale social review. 


\subsection{Integration of water policy into the sector policies}

Between 2000 and 2010 key attention was paid to the integration of water protection and water management policy into other sector-policies, meaning that the EU water protection policy was extended by way of integration with other water management policies and sector policies, such as:

- Integration of traffic (water transportation) policy and water protection policy (outcome: Common Statement on the development of sustainable waterway).

- Integration of Common Agricultural Policy and water protection policy (outcome: Rural Development Plans).

- Integration of energy/renewable energy and water protection policy.

- Sustainable hydraulic power generation.

\subsection{Policy documents}

In order to implement the new policies, rules and other legal papers were established:

- 2007: Flood-risk management directive

- 2008: Marine Strategy Framework Directive

- 2009: Drought and water shortage strategy and labor program

- 2010: Climate policy and strategy

The existing water protection directives have also gone through some development:

- 2006: Directive on underground waters

- IPCC Directive had been amended four times until 2008.

The Environmental Impact Assessment (EIA) Directive, Strategic Environmental Assessment (SEA) and the building of NATURA 2000 network are of increasing importance.

The role of integration in the enforcement of water protection aspects is also reflected in large-scale development programs:

- Baltic Sea Region Program of the EU. Objectives: to protect the water body of the sea and protect waters all over the sea basin (in accordance with the provisions of the Water Framework Directive and Marine Strategy Framework Directive). A new water protection policy element is the protection of marine waters.

- The Danube Macro-Region Strategy of the EU. Objectives: to protect water quality in Danube river basin and protect the water along seashores in line with the provisions of the Water Framework Directive.

\section{Introduction of the environmental complex knowledge space and the SEA as an application thereof}

There were many efforts in the last two decades to analyze the relations between the environment utilization and the change of resource kit and environmental 
status. This is reflected in the development of environmental problem space model and the model of environment management and analysis (Bulla [1-3]) the OECD model (PSR, PSIR), the UN model (UN National Statistical Division [4]) and the EU model (DPSIR).

With a view to these models we attempt to outline an expert system which includes all the potential and considerable components of analyses. The framework of the system resembles the "problem space", where intersections of environment utilizations (loads) and changes of environment status (i.e. the changes of natural resource kits) are the stages or platforms (as called in Information and Computing Technology) of complex and multidisciplinary impact analyses, which inherently comprise ecological, economic, technological, social, etc. aspects. A bit more specifically, this means that the analysis of impacts and triggered impacts and interactions need heterogeneous sets of technical-economic-legal data and information, and, in addition to the inter- and multidisciplinary management of disciplinary-structured knowledge bases, the interoperability shall also be ensured - these efforts all call for IT applications and application developments.

In addition to creating meta databases we also need to analyze the relations of these databases. It is recommended to create virtual platforms to overview the conclusions and visualize the results. This is increasingly less, or even not, possible without the use of 3D or, recently, virtual 4D IT applications.

So the complex space of environmental analysis shall include relevant information to all environment statuses, environment loads and rules, plans and programs of environment utilization. This can be achieved by structuring the information into "knowledge bases" (Figures 1 and 2).

All policies, sectorial or regional development programs shall be implemented in this space, or its feasibility shall be studied in the system of rules that prescribe the environment status, the degree of resource utilization and/or load bearing limits. The analysis of interactions with other plans and programs and positive and negative synergies shall also be performed in this space. For this reason the "cassettes" of layers created by rows and columns of the spatial matrix of the complex problem space shall be filled with knowledge bases. The initial contents of knowledge bases are shown in the recommended lists of this chapter - these contents shall, naturally, be regularly maintained, selected and updated.

The recommended elements and the establishment of the knowledge base can be summarized as follows:

- $\quad$ selection (for example: OECD [5], KSH [6], EAA [7], CEROI [8]) and creation (for example Zseni [9]) of (some) indicators depending on the objective to be presented and availability of basic data;

- overview, determination of the relevance of control(s), review of conclusions;

review of different (development) programs, determination of relevance, review of consequence(s) and positive/negative synergies. 


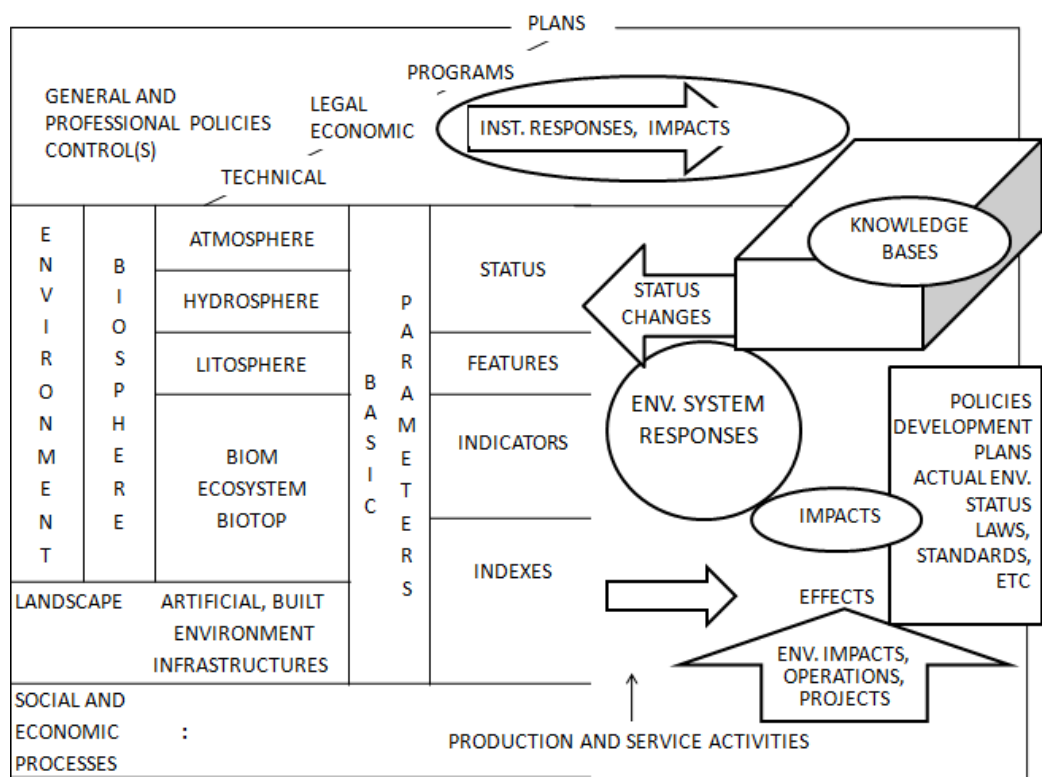

Figure 1: The complex environmental problem space (source: Bulla [10]).

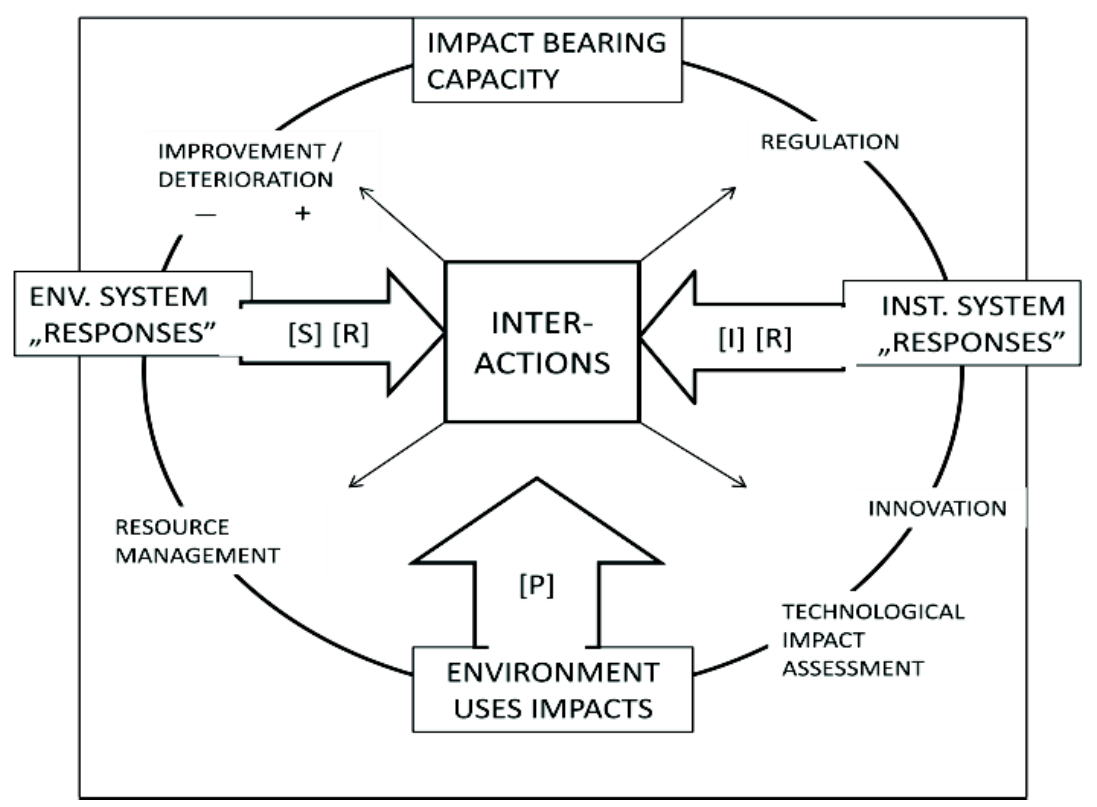

Figure 2: $\quad$ Environmental analysis - a multidisciplinary analysis of factors in the complex knowledge space [KxTT] (source: Bulla [10]). 
In the following part of the chapter we give an overview of the factors of environmental resource management, i.e. the knowledge base of the complex space.

\subsection{Components of the environmental status and resource kit (Status)}

The resource kits, which represent the highest level of integration, and the complex indices related to their use, i.e. the datasets building up the status indicators and listing the essential parameters of the "elements" forming the systems can be organized into a scheme where the development of indicators and the increase of their accuracy can easily be tracked, ranging from "impressions" through measured data to the complex indicators supported by model calculations (Figure 3).

\begin{tabular}{|c|c|c|}
\hline $\begin{array}{c}\text { AGGREGATED } \\
\text { INDICATORS, INDICES }\end{array}$ & $\begin{array}{l}\text { STATUS, SET } \\
\text { INDICATORS }\end{array}$ & BASIC PARAMETERS \\
\hline ENVIRONMENT & FLORA, FAUNA & ATMOSPHERE \\
\hline LANDSCAPE & SETTLEMENTS & HYDROSHPERE \\
\hline REGION & INFRASTRUCTURE & LITHOSPHERE \\
\hline
\end{tabular}

$\left[\begin{array}{cc}\text { THE ACCURACY OF RESOLUTION } & \text { ANALYSIS } \rightarrow \\ \hdashline \text { SYNTHESIS } & \text { INFORMATION CONTENT }\end{array}\right]$

Figure 3: Complexity of indices (source: Bulla [10]).

\subsection{The effects of environment utilization and impacts}

The study of partial operations by means of essential status indicators is unsuitable for a decision making analysis and forecast of the changes in largescale environmental resource utilization (e.g. development programs, economic structural change, etc.) This technology represents the level of environmental impact assessments (EIA). The analysis of complex processes, however, calls for indicators that include a set of aggregate information. Based on the review of available attempts (Verbruggen [11], OECD [5]) we propose the use of the following six multi-component aggregate indices: 
1. the change of land utilization;

2. utilization of water (and waste-water);

3 . the change of energy utilization;

4. generation of (excess) transports;

5. the quantity and composition of waste;

6. the degree of biodiversity (change).

The proposed indices are (may be) suitable for the characterization of both the utilization as well as the change in stock and status (Figure 4). This is a key benefit in the execution of compact analyses characterized by high information density.

\begin{tabular}{|ccc|}
\hline USES & $\begin{array}{c}\text { IMPACTS } \\
\text { (EMISSIONS) }\end{array}$ & $\begin{array}{c}\text { SETS, STATUS } \\
\text { (IMMISSION) }\end{array}$ \\
\hline Use of land & to ground & Use of land \\
Use of water & to water & Soil quality \\
Use of energy & to atmosphere & Water resource, quality \\
Transport & to biosphere & Inhabited environment \\
Waste & to built environment & Biodiversity \\
Biodiversity & & \\
\hline
\end{tabular}

Figure 4: Indicators of environment utilization and impact (source: Bulla [10]).

\subsection{Components of the development of environmental resource utilization - controls, plans, programs ( Response)}

The aim of the analysis/evaluation is to review the interactions of environmental systems consisting of, or formed by, different activities, interventions and individual or all of the environmental elements on the affected area. This method and the technology to be developed for the application makes possible the gathering as well as analysis of the adequate information as the base of the elaboration of alternatives for regulation and intervention of the social,economical processes which impact the state of environment.

The criteria of State Evaluation of Environment (SEE) shall include the definition of the term environmental element or systems as well as the term and extension of the area affected. The analysis of the status of fauna of a given area (including the human) shall cover the study of land and aquatic ecosystems as well as the atmosphere, while in the case of landscape or inhabited areas, the scope of analysis shall cover the artificial (built) elements of the environment as well as the change of resource kits, too.

The resolution of analysis and, in turn, the accuracy and feasibility of casual exploration of (inter)actions will depend on the size of the area selected. In line with the international experience, the attention shall be focused on local and regional level, where development policies, actions and effects can actually be 
analyzed. Although global reports can be made on changes, the actual decisionmaking, implementation, effect analysis and/or forecasting processes should be based on local or regional level (Figure 5).

\subsection{The combination of development policies and factors of environment utilization}

The proposed aggregated indices are (may be) suitable for the analysis of both the environment utilizations and impacts as well as the characterization of change in stock and status. Figure 5 was prepared to introduce this analysis model.

The combination of development policy tracts, impact and status factors

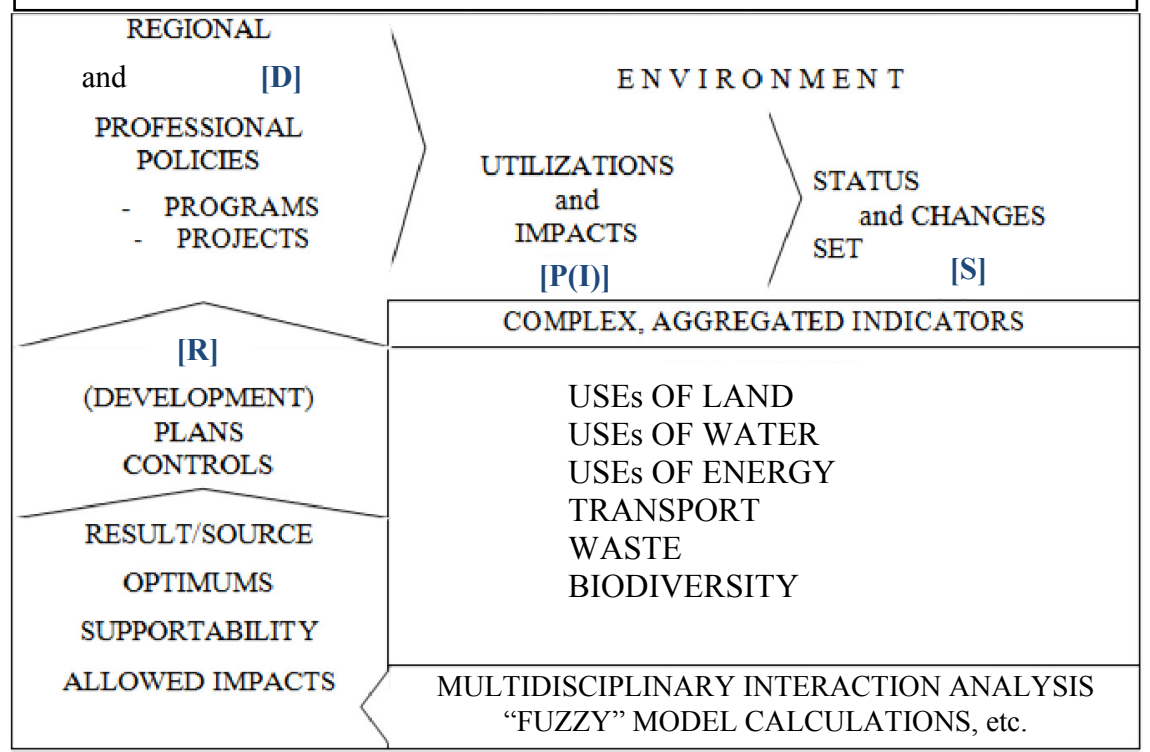

Figure 5: The combination of development policy tracts, impact and status factors (source: Bulla [10]).

\section{Assessment of relevance of rules}

During developments we have to pay attention to specific technological realizations, economic and social consequences, environmental effects, actual regulations of a given (geographical) area and other earlier/current/future developments, since our ideas should be realized in a realistic environment instead of a "pure" space. This means that our development (our policies, ideas, actual projects) should be integrated into the system of existing rules, other policies, projects, plans, strategies and material consequences (impacts on water, land, atmosphere, fauna and built environment). 


\subsection{Laws}

An essential part of any expert system is the up-to-date knowledge of the current legislative background. We do not wish to list the relevant Hungarian laws, governmental and other sectorial decrees in this paper. However, the laws and a unit that monitors the change of laws should be integrated into the decision making system to be developed.

\subsection{Methodology}

A search engine is to review the entire set of laws to find those that are relevant to the actual development program(s).

\section{Relevance of other programs}

The knowledge and consideration of other relevant programs affecting the given region is inevitable during the planning, implementation and evaluation of a development project. Introduction of methodology: a search engine is to review all sectorial and regional developments programs to find those that are relevant to the actual development and to determine any interactions and positive/ negative synergies that may arise.

\subsection{River basin management plan(s)}

The River Basin Management Plan is the implementation tool of the Water Framework Directive (WFD). The term "river basin" in WFD is a land from where all surface watercourses flow (possibly through a series of lakes) to the sea. As the entire area of Hungary belongs to the river basin of the Danube, we had to prepare a river basin management plan for the whole area of the country (as part of the Danube RBMP) and for 4 partial water catchment areas: the part of Danube river basin that connects directly to the Danube river, the part of Dráva river basin that falls within the borders of Hungary, the part of Tisza river basin that falls within the borders of Hungary and the water catchment area of lake Balaton. Due to the result of an effective social interaction and practical reasons, the partial water catchment areas have been divided into 42 planning sub-units (Figure 6).

The plan gives a detailed overview of the current status of Hungarian surface and underground water resources, the schedule of objectives and the planned actions based on the real situation and economical calculations, which, hopefully, will be adequate to bring all our surface and underground watersheds into a good status by 2027 . The most important tasks related to the protection of surface and underground waters are the preparation, planning and implementation of these actions, which affect several sectors. 


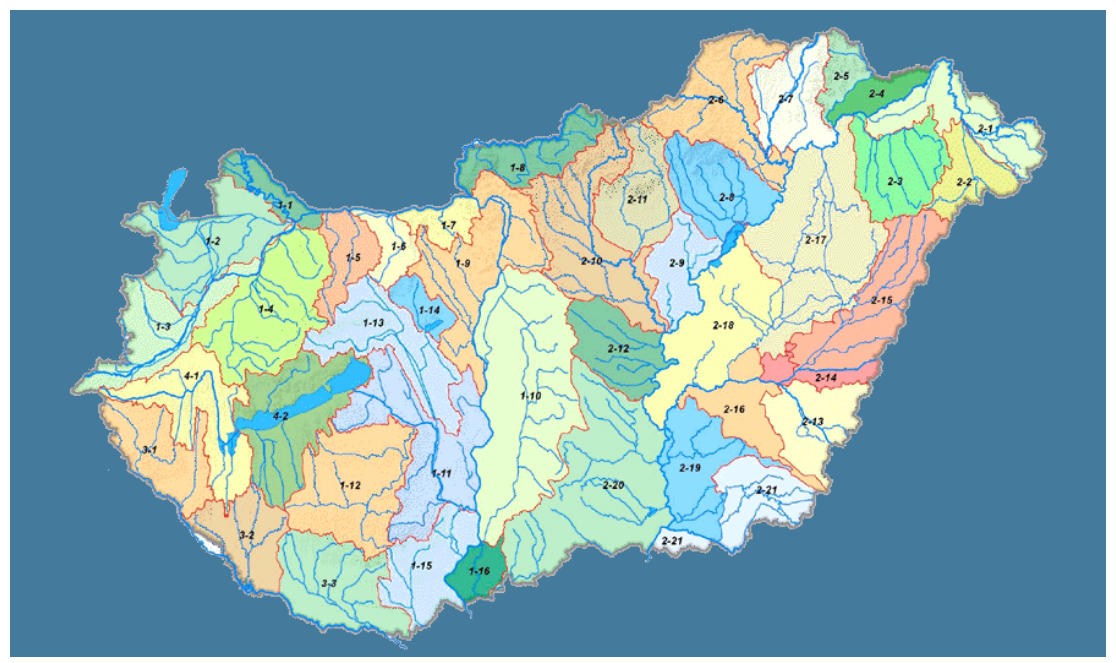

Figure 6: Catchment planning subunits (source: VKKI [12]).

\section{2 "Vásárhelyi plan", an example of a complex RBM and RD program}

The main goal of the Development of Vásárhelyi Plan (DVP) is to enhance the safety against the over-flow as well as improve capacity of sustainable land use in Tisza valley. In addition to flood control development, the program contains infrastructural developments (municipal drainage, sewer development, construction of bicycle roads) and the introduction of farming practices that adapt to the natural conditions, including landscape management, as well.

One of the key principles of the DVP is to create a spillway system consisting of structures and reservoirs (which enable the controlled discharge and recirculation of flood water to the river-bed or possibly draught areas) so that this system can also be utilized for the attainment of goals related to the development of Tisza valley as well as the enrichment of natural habitats.

\section{Conclusion}

The planning and/or (ex ante) assessment of sustainable environmental resource management as well as the modeling (or at least estimation) of adequacy and results of regulation policies is a typical example of a problem with extreme information demand. It can be resolved by algorithms applicable for revealing relations of highly complex systems, which generally means the application of artificial intelligent and (in a broader sense) the ICTs for implementation (Bulla [2]): a multidisciplinary navigation between heterogeneous databases on virtual process management (4D) meta surfaces. The main goal of environmental analysis is, therefore, the combination of environmental sciences and ICT applications, or more specifically, assessment and multi-faceted analysis of the 
effect of industrial, agricultural, service activities, local and regional development programs, investment projects to the natural and social environment. Such a problem is not linear and not deterministic; it is a typical example of highly complex systems, which call for the generation of algorithms between sets of fading borders, and the solution of operations by means of intelligent calculation tools. From information technology point of view, this needs the development of an application which enables the management, transmission, storage of heterogeneous datasets with absolutely different structure (and contents) as well as is able to flexibly serve different user needs. It should also enable the generation of virtual platforms suitable for interoperability (i.e. generation and connection of knowledge bases) and, in turn, can reveal interactions and visualize the results. The development of environmental analysis consists of the solution of these tasks and the application of the results.

\section{References}

[1] Bulla, M., Environmental model: an analysis on the relations of the components of environmental management. In: Environmental Engineering Education and Training. p: 151-159. Ed.: T.V. Duggan, C.A.Berebbia: Wessex Institute of Technology, UK, 1996

[2] Bulla, M. (ed.): Komplex környezetállapot-értékelő szakértői rendszerek metodikai fejlesztése, Kutatási összefoglaló. Széchenyi István Egyetem, Környezetmérnöki Tanszék (RD summary ), 2004

[3] Bulla, M.: A környezetgazdálkodási modell regionális alkalmazása, IX. Környezettudományi Tanácskozás, Széchenyi István Egyetem, Környezetmérnöki Tanszék (RD summary CD), pp. 3-13. 2009

[4] Indicators of Sustainable Development: Framework and Methodologies. United Nations, New York, 1996

[5] OECD: OECD Core set of indicators for environmental performance reviews. A synthesis report by the Group on the state of the Environment (Environment monographs n83), 1993

[6] KSH: A fenntartható fejlődés indikátorai Magyarországon 2008. (Indicators of SD, Hungarian Central Statistical Office, 2008.) Ed.: Laczka, É., 2008

[7] Environmental signals 2000. - European Environment Agency regular indicator report Eurostat "Measuring progress towards a more sustainable Europe, 2007” (http://epp.eurostat.ec.europa.eu/portal/page/portal/sdi/ indicators)

[8] CEROI: City Environmental Indicators from CEROI (http://www.ceroi.net/) Project Co-operation: International Council for Local Environmental Initiatives (ICLEI); Partners : http//:www.ceroi.net/ inform/kinks.htm

[9] Zseni, A.: Regionális környezethasználatok és fejlesztések fenntarthatósági vizsgálata - A vízterhelések indikálása., X. Környezettudományi Tanácskozás, Széchenyi István Egyetem, Környezetmérnöki Tanszék, (RD summary CD), pp. 38-55., 2010 
408 Water and Society

[10] Bulla, M.: A regionális fejlesztési-politikák környezethasználati indikátorai, X. Környezettudományi Tanácskozás, Széchenyi István Egyetem, Környezetmérnöki Tanszék (RD summary CD), pp. 4-37., 2010

[11] Verbruggen, A.: Annual Report of WG Energy and Environment, University FSI Antwerpen, 1997

[12] VKKI (Vízügyi és Környezetvédelmi Központi Igazgatóság): A Duna vízgyüjtő magyarországi része vízgyüjtő-gazdálkodási terve, P445, 2010 